\title{
Ten year transitions in children's experience of living in a workless household: variations by ethnic group
}

\section{Lucinda Platt}

Institute for Social and Economic Research, University of Essex

\begin{abstract}
Over the last few decades, there has been an increase in the proportion of children growing up in workless households, that is households in which no adult member is in paid work. This proportion has stabilised, and has declined slightly in recent years. Worklessness among households with children is viewed as a cause for concern for two reasons: firstly, because children in workless households are much more likely to be growing up in poverty; secondly, because of concern that worklessness in families with children may be subject to intergenerational transmission.

We know surprisingly little about children's experience of household worklessness over time, particularly over their childhood as a whole, even though worklessness is heavily implicated in higher poverty risks. Children from most minority ethnic groups are at substantially higher risk of household worklessness than those from the majority. For some ethnic groups, children's rates of living in a workless household are associated with high rates of lone parenthood. For others it is worklessness in couple parent families that predominates. This article uses the Office for National Statistics (ONS) Longitudinal Study to explore differences in risks of worklessness over time, among ethnic groups within a single cohort of children who are observed at two time points, 10 years apart.
\end{abstract}




\section{Contents}

Abstract 70

Introduction 72

Data and study design. 77

Results 80

Discussion 85

Acknowledgments 86

Appendix. 87

References 87

\section{List of figures}

Figure 1 Proportions of children in workless households at 1991 (aged 0-5 years) and 2001 (aged 10-15 years) by ethnic group, England and Wales.

Figure 2 Movers and stayers, children in workless households 1991-2001, by ethnic group

Figure A1 Employment status by gender and ethnicity (percentages).

\section{List of tables}

Table 1 Recent estimates of proportions of children living in a workless household and living in a poor household by ethnic group (percentages)

Table 2 Children in lone parent families by age group and ethnic group; risk of living in a workless household for children in lone parent family

Table 3 Children aged 0-5 years in 1991 and observed aged 10-15 years in 2001 by ethnic group, England and Wales.

Table $4 \quad$ Relative chances of being in a workless households in 2001 conditional on 1991 workless household status, by ethnic group. 


\section{Introduction}

\section{Children living in workless households}

The last decade has seen a growing research and policy interest in workless households, that is households where no one of working age is in work. ${ }^{1,2,3}$ A particular concern has been the welfare and future prospects for children in such households. ${ }^{4,5,6}$ Attention has focussed on the differential risks of living in a workless household faced by children from different ethnic groups. We still know little about how worklessness is experienced over time, and how that may or may not differ by ethnicity. This is of particular concern, since children from many minority ethnic groups are at relatively high risk of living in a workless household and of the poverty stemming from that. ${ }^{7}$

This article focuses on a particular cohort of children, born around the end of the 1980s, and investigates the currently unexplored question of whether risks of remaining in or moving into a workless household during their childhood are comparable for children from different ethnic groups. It describes absolute differences in risks of remaining in or entering a workless household across groups, and examines the extent to which any differences are mediated by household structure and characteristics. For the purposes of this article, a workless household is defined as one where no adult member is in work. ${ }^{8}$

The increase of work work-rich and work work-poor households has been well documented. Gregg and Wadsworth ${ }^{3}$ have shown how the share of workless households increased over the last two decades of the 20th century with some levelling off by 2001 , and that this was the case for households with children as well as for all households. Indeed, in 1996 the UK had the highest proportion of workless households with children in the member countries of the Organisation for Economic Cooperation and Development (OECD). At the same time there has been a longstanding interest in, and concern with, the potential transmission of various forms of economic disadvantage between generations, ${ }^{9}$ and with how children's experience of such disadvantage, including worklessness, can have long term impacts.

Children's risks from living in a workless household tend to be higher when they are younger and tends to decline with age, ${ }^{10,11}$ but experience of a workless household can have negative consequences at any age, and growing up in a persistently workless household is likely to be particularly detrimental to future outcomes.

Children living in workless households face very high risks of living in poverty, and the associations between childhood poverty and future outcomes, ${ }^{12}$ as well as their development, ${ }^{13}$ are well attested. Moreover, persistent poverty both tends to represent more severe poverty and to be associated with more negative outcomes than short-term or transient poverty. ${ }^{14}$ Thus, to the extent that it implies long-term poverty, long-term worklessness is likely to be of particular concern in relation to children's welfare. The timing can also have implications for children's later life outcomes. Poorer outcomes associated with poverty and worklessness tend to be greater for younger rather than older children ${ }^{10,11}$ and it is also at younger ages that the risks of living in a workless household are greatest. Nevertheless, Ermisch et al. ${ }^{11}$ have shown that the experience of worklessness in later childhood (11-15 years) is associated with increased chances of smoking and of psychological distress.

While there has been substantial emphasis on the detrimental effects of long-term poverty or worklessness, increasing attention is being paid to the negative impacts of socio-economic instability in its own right. ${ }^{15,16,17,18}$ Instability provides the opportunity for periods of relative advantage 
compared to remaining persistently below a given poverty threshold such as 60 per cent of median equivalent household income, as used in UK low income statistics. ${ }^{19}$ However, those who fluctuate between states are likely to be in more marginal positions - on the borders of poverty or on the margins of work ${ }^{16}$, while the actual variation in circumstances may introduce its own costs, such as uncertainty, the need to reclaim benefits with the consequent possibility of periods without any support, the need to change arrangements for care, and so on. Therefore vulnerability to poverty, as evidenced by subsequent moves into worklessness, raises concerns for family welfare.

In addition to the welfare implications of growing up in a workless household, the experience or persistence of worklessness among families with children, which typically implies a need for support by state benefits, has raised concerns about the extent to which there is intergenerational transmission of worklessness and benefit dependence. ${ }^{9}$ Evidence from the US provides supporting evidence for intergenerational transmission of 'welfare' participation, ${ }^{21}$ over and above income effects, though the exact mechanisms are not clearly understood. Both lack of role models and limited access to networks and opportunities for pursuing employment - or a combination of these - have been offered as explanations for intergenerational transmission.

There are good reasons for being concerned about children's rates of living in a workless household, their risks of being persistently in a workless household and their vulnerability to ending up in a workless household from a working household. However, there is little understanding of the extent to which these risks differ for children according to their ethnicity, and the factors implicated in differential risks. This is despite the fact that it is well known that there are higher risks of poverty for children from certain ethnic groups, and that the risks of being in a workless household also vary substantially by ethnicity, as the next section discusses. Although there are some indications of differences in persistence and instability in economic circumstances across ethnic groups, ${ }^{22}$ we have little understanding of how transitions into workless households, or persistence in growing up in a workless household across childhood over an extended period, varies by ethnic group. The contribution of this article is to explore precisely these questions for a particular cohort of children of the same age and over the same period.

\section{Ethnicity and worklessness}

Individual employment rates are well known to vary by ethnicity, particularly for women, with high rates of inactivity among Pakistani and Bangladeshi women, relatively high levels of participation among Black Caribbean women, relatively high rates of inactivity (compared to other men) among Bangladeshi men and above average unemployment risks for all minority groups (see Appendix, Figure A1). A substantial body of research has shown that some minority groups are disadvantaged in the labour market, even taking account of variation in qualifications and other job-relevant characteristics ${ }^{23}$. However, far less is known about the duration of unemployment or worklessness across ethnic groups even at the individual level; nor do individual levels of employment - analyses of which abound ${ }^{24}$ - tell us about the same phenomenon as household experience of work and non-work.

Cross-sectional analyses indicate that there are clear differences in workless household rates by ethnic group; we also know that there are substantially higher rates of cross-sectional child poverty among all minority groups compared to the majority. Table 1 shows that for most recent estimates, children's risks of living in a workless household were particularly high for Black African children and lowest for Indian children. There are substantial differences between the groups and the rates 


\section{Table $1 \quad$ Recent estimates of proportions of children living in a workless household and living in a poor household by ethnic group (percentages)}

\begin{tabular}{|c|c|c|c|c|}
\hline & \multicolumn{2}{|c|}{$\begin{array}{l}\text { Children's household } \\
\text { workless (per cent) by } \\
\text { ethnic group of child }\end{array}$} & \multicolumn{2}{|c|}{$\begin{array}{r}\text { Children's household poverty } \\
\text { (per cent) by ethnic group } \\
\text { of head of household }\end{array}$} \\
\hline & 2009 & 2001 & 2004/05-2006/07 & 2001/02-2003/04 \\
\hline White & 15.4 & 14.8 & 20 & 20 \\
\hline Mixed & 27.9 & 28.6 & - & - \\
\hline Indian & 8.6 & 10.4 & 27 & 28 \\
\hline Pakistani/Bangladeshi & 25.1 & 34.8 & $54 / 58$ & $59 / 72$ \\
\hline Black Caribbean & 30 & 27.4 & 26 & 31 \\
\hline Black African & 42 & 50.1 & 35 & 38 \\
\hline Other Black & 26.8 & 36.8 & - & - \\
\hline Chinese & 13.9 & 23.4 & - & - \\
\hline
\end{tabular}

Notes: '-' = figures not available due to small sample sizes. Children refers too children aged under 16.

Sources: Column 1: ONS Statistical Bulletin 'Work and worklessness among households 2009', Table 3(iv) (from Labour Force Survey) UK data; Column 2: Platt 2009, Table 2.1 (from Family Resources Survey), data for Great Britain

for minority groups are significantly different from those for the White majority. Given that, in this article, rates of living in a workless household are considered for 1991 and 2001, Table 1 also illustrates the rates that pertained across groups in 2001. While the rates are rather different for some groups at the earlier period, the ranking is very similar for the two time points, with the major change being the reversal of the relative positions of Black Caribbean and Pakistani/Bangladeshi children.

It can also be seen from the right hand panel of Table 1 that the ranking of workless household risks does not map precisely onto poverty rates. Worklessness is of concern in part because it brings high risks of poverty, but poverty is not fully accounted for by worklessness. As Nickell ${ }^{6}$ pointed out in his discussion of children and workless households, 53 per cent of poor children lived in workless households in 2000/01, and those living in workless households had a 70 per cent chance of being poor. However, there is not a complete overlap. Nevertheless, worklessness may have implications for future welfare over and above the material deprivation that it is likely to bring.

It is known that family structure varies substantially between groups. For example, Black Caribbean and Black African children experience high rates of lone parenthood, and children from South Asian groups are much less likely to live in a lone parent family (see Table 2). The trend with age is towards higher risks of living in a lone parent family, but this is counteracted by the greater likelihood of lone parents with older children being in work. Recent policy changes are intended to enhance this pattern. ${ }^{25}$ Since we know that family structure, in particular lone parenthood, is heavily implicated in risks of worklessness, we might therefore expect that such variations in family structure would influence absolute risks of worklessness, despite the greater propensity of Black Caribbean lone parents to be in employment compared to other lone parents. This is reflected in Table 2, where children's risks of living in a workless household, given that they are in a lone parent family, is shown. 


\begin{tabular}{|c|c|c|c|c|c|}
\hline \multirow[t]{2}{*}{ Ethnic group } & \multicolumn{3}{|c|}{ Percentage in lone parent family } & \multirow{2}{*}{$\begin{array}{r}\text { Risk of household } \\
\text { worklessness in } \\
\text { lone parent family: } \\
\text { percent [C. I.] }\end{array}$} & \multirow[b]{2}{*}{ Number } \\
\hline & $\begin{array}{r}\text { All children } \\
\text { [C.I.] }\end{array}$ & $\begin{array}{r}\text { Age 0-5 } \\
\text { [C. I.] }\end{array}$ & $\begin{array}{r}\text { Age } 10-15 \\
\text { [C. I.] }\end{array}$ & & \\
\hline White British & $\begin{array}{r}24 \\
{[24-25]}\end{array}$ & $\begin{array}{r}21 \\
{[21-22]}\end{array}$ & $\begin{array}{r}27 \\
{[26-27]}\end{array}$ & $\begin{array}{r}45 \\
{[44-46]}\end{array}$ & 37,362 \\
\hline White \& Black Caribbean & $\begin{array}{r}52 \\
{[44-61]}\end{array}$ & - & - & $\begin{array}{r}58 \\
{[47-69]}\end{array}$ & 141 \\
\hline White \& Asian & $\begin{array}{r}16 \\
{[11-22]}\end{array}$ & - & - & - & 166 \\
\hline Indian & $\begin{array}{r}10 \\
{[8-12]}\end{array}$ & $\begin{array}{r}8 \\
{[5-11]}\end{array}$ & $\begin{array}{r}12 \\
{[9-17]}\end{array}$ & $\begin{array}{r}51 \\
{[41-61]}\end{array}$ & 887 \\
\hline Pakistani & $\begin{array}{r}16 \\
{[14-19]}\end{array}$ & $\begin{array}{r}11 \\
{[8-14]}\end{array}$ & $\begin{array}{r}21 \\
{[16-27]}\end{array}$ & $\begin{array}{r}62 \\
{[52-70]}\end{array}$ & 923 \\
\hline Bangladeshi & $\begin{array}{r}11 \\
{[8-15]}\end{array}$ & $\begin{array}{r}7 \\
{[4-12]}\end{array}$ & - & - & 417 \\
\hline Black Caribbean & $\begin{array}{r}56 \\
{[52-60]}\end{array}$ & $\begin{array}{r}54 \\
{[47-62]}\end{array}$ & $\begin{array}{r}58 \\
{[52-66]}\end{array}$ & $\begin{array}{r}39 \\
{[34-45]}\end{array}$ & 583 \\
\hline Black African & $\begin{array}{r}46 \\
{[43-50]}\end{array}$ & $\begin{array}{r}40 \\
{[34-46]}\end{array}$ & $\begin{array}{r}51 \\
{[45-58}\end{array}$ & $\begin{array}{r}65 \\
{[59-70]}\end{array}$ & 760 \\
\hline
\end{tabular}

Note: Figures are weighted. '-' indicates that sample sizes are too small to allow for reliable estimates.

Source: Family Resources Survey 2001/02-2006/07, pooled. Author's analysis

Whether family structure does account for differences in overall risks of worklessness over time, when considering children of a comparable age and a common cohort, is a question addressed by this article.

There are also variations in average family size according to ethnic group, with Pakistani and Bangladeshi families in particular having larger family sizes on average. Additional children may make moves out of worklessness more difficult, both as a result of the demands they make on parental time and as a result of the structure of benefits and the impact on marginal tax rates. On the other hand, as children grow up they may provide additional sources of labour market income for families as they remain in the home.

It is therefore not clear what the different chances are likely to be of moving into, or remaining in, a workless household over the childhood years, for different groups.

What neither Table 1 nor Table 2 reveals are the risks of worklessness for children of particular ages and family ${ }^{26}$ circumstances, nor is there information on risks of long-term worklessness, or the nature of transitions to and from worklessness. These are addressed in this article.

\section{Aims of current analysis}

This article sets out to map the patterns of children's workless household transitions, for children from different ethnic groups. It asks:

- What are the differences in risks of worklessness for a single cohort of children according to their ethnic group? 
- What are the chances of remaining in a workless household (persistence) or ending up in a workless household after having been in a working household (entry), for children from different ethnic groups?

- To what extent are experiences of workless household persistence and entry significantly different for children from particular minority groups, compared to White majority children?

- To what extent are such differences mediated by family and household context?

- And conversely, to what extent do greater risks appear to exist over and above the contribution of relevant household and family characteristics?

The analysis is motivated by the implications raised, by the differential chances of remaining workless, for children from minority ethnic groups. In absolute terms, any differences in vulnerability to remaining in or entering a workless household may have implications for the future wellbeing of children from those groups, and therefore merits attention. Understanding the role of family and household characteristics can inform and reinforce strategies to address these areas. If those differences are largely mediated by household and family characteristics, such as the emphasis on moving lone parents into work, then there is less argument that policy should be differentiated to address the risks of different groups.

Conversely, if there appear to be ethnic differences in children's risks of staying in or moving into a workless household even after taking account of relevant family and household characteristics, then such ethnic penalties ${ }^{27}$ in children's risks of worklessness require further explanation, and possibly targeted intervention. It should be noted however, that the extent to which the long-term impacts of worklessness are themselves comparable across ethnic groups, including transmission of deprivation, is as yet untested and is an area for future research.

The following analysis explores transitions into and out of workless households over a ten year interval by ethnic group, using a unique data set, the ONS Longitudinal Study (see Box one). It examines the risks of living in a workless household for a cohort of children born between 1986 and 1991, when they are young (0-5 years old) at the beginning of the 10 year window in 1991 and when they are older (10-15) at the other end of the observation window in 2001. It explores their chances of remaining in, moving into or moving out of a workless household between these two time points, and how those chances vary by ethnic group. It cannot be assumed that the households will have been workless throughout the whole period demarcated by the two measurement points. Indeed, we can expect substantial fluctuation in family and household circumstances. However, those who are continuously workless will be overrepresented at the second time point compared to those moving in and out. Moreover, it is relevant to observe that there is an association between worklessness at a ten year interval, even if there have been shorter moves out of worklessness within the period.

The article estimates these chances, controlling for both household and family characteristics associated with the chances of living in a workless household, such as family composition, parental qualifications, access to a car and housing tenure. It also examines the contribution of changes in circumstances during the observation window, such as parental separation, change in family composition, or geographical mobility.

By estimating models, both with and without these additional explanatory and control variables, it is possible to measure the extent to which family and household characteristics account for observed 
differences in patterns of worklessness between ethnic groups, or conversely, the extent to which residual 'ethnic penalties' remain.

\section{Data and study design}

\section{Data and sample}

This article makes use of an extract based on a cohort of LS members who were children aged $0-5$ in 1991 and who were linked to their records in 2001 when aged 10-15. Information on the households and those enumerated in the households (the non-members in the data) at which the study members were living at either point in time also formed part of both extracts.

The children had to be observed at two time points in order to be included in the sample. This means they will not precisely reflect the overall populations of children aged 0-5 in 1991 or aged 10-15 in 2001. However, those children who join the LS during the decade (via immigration or return) are not a concern of this analysis of transitions, and any potential bias stemming from systematic differences in those observed at 1991 but not responding in 2001 is anticipated to be marginal. ${ }^{28}$

\section{Box one ONS Longitudinal Study data}

The ONS Longitudinal Study (LS) contains linked census and vital event data for one per cent of the population of England and Wales. Information from the 1971, 1981, 1991 and 2001 censuses has been linked across censuses as well as information on events such as births, deaths and cancer registrations. The original LS sample included 1971 Census information for people born on one of four selected dates in a calendar year. These four dates were used to update the sample at the 1981, 1991 and 2001 censuses and to add new members between censuses. New LS members enter the study through birth and immigration. Data are not usually linked to a member after their death or after de-registration from the NHS Central Register but these members' records remain available for analysis.

Census information is also included for all people enumerated in the same household as an LS member, but only information on LS members is linked over time.

\section{Ethnic group}

Children's ethnic group was allocated on the basis of their (non-imputed) ethnic group in 2001. Where ethnic group information was missing for 2001, the 1991 response and parental ethnic group were used to allocate ethnic group as far as possible. The approach for adding information from parents' ethnic group was carried out on the basis of the observed patterns of parents' and children's ethnic group in the non-missing data. Therefore, where couple parents had the same ethnic group as each other, the child was given the ethnic group of the parents. Among the remainder, where two parents were from different white ethnic groups, the child was attributed White British ethnicity. Where the two parents were from different ethnic groups, these were mapped onto the appropriate mixed categories. This left some missing cases where only one parent was present. It is not possible to assume that lone parent and child share the same ethnic group, and so these few cases were excluded from the analysis.

Table 3 shows the number of children included in the analysis by ethnic group. There were rather small numbers of children from some ethnic groups, rendering them unsuitable for detailed 


\section{Table $3 \quad$ Children aged $\mathbf{0 - 5}$ years in 1991 and observed aged 10-15 years in 2001 by ethnic group, England and Wales}

\begin{tabular}{lrr}
\hline Ethnic group & Total in group & Per cent of sample \\
\hline White British & 33,166 & 90.2 \\
White Irish & 119 & 0.3 \\
White Other & 304 & 0.8 \\
White and Black Caribbean & 394 & 1.1 \\
White and Black African & 75 & 0.2 \\
White and Asian & 228 & 0.6 \\
Other Mixed Group & 161 & 0.4 \\
Indian & 757 & 2.1 \\
Pakistani & 564 & 1.5 \\
Bangladeshi & 212 & 0.6 \\
Other Asian & 123 & 0.3 \\
Black Caribbean & 262 & 0.7 \\
Black African & 135 & 0.4 \\
Other Black & 97 & 0.3 \\
Chinese & 113 & 0.3 \\
Other ethnic group & 63 & 100 \\
Total & 36,773 & 100 \\
Missing ethnic group & 394 & 1.1 \\
Total including missing & 37,167 & 100 \\
\hline
\end{tabular}

Source: ONS Longitudinal Study, author's analysis

consideration, though they were included in the estimations for completeness. Small sample sizes were particularly an issue for White Irish, White and Black African, and Chinese children, as they were for the heterogeneous 'other' groups: Other Mixed, Other Asian, Black Other and Other.

The illustration of results and the discussion therefore focus on the larger groups: White British, White Other, White and Black Caribbean, White and Asian, Indian, Pakistani, Bangladeshi, Black Caribbean and Black African.

\section{Workless household}

For the purposes of this article, the definition of a workless household is that no member of the household was in paid work, either full-time or part-time. To construct the workless household variable, the non-members file was used, providing information on those co-resident with the LS member at each measurement point.

\section{Additional explanatory and control variables}

The non-members file was also used alongside the members file to enable the construction of variables to indicate whether:

- the sample member was living with both parents or just one at either time point

- whether the co-resident parent(s) were UK born, and their educational level 
- the age of the mother

- whether the parents had experienced separation, widowhood or divorce within the decade

- how many siblings were co-resident, whether this changed between the two time points, and whether there was a child aged under five in the household at the later time point

Research suggests that all these are likely to influence the chances of adult household members being in work, and therefore the chances of a household being or becoming jobless.

Household level variables on car ownership and housing tenure were also included, as was a measure of change in housing tenure. These variables are indicative of financial resources which may assist maintenance of family work and protect against adverse circumstances. They have been shown to be more directly related to employment outcomes. Access to a car, or at least possession of a driving licence, has been shown to be important in facilitating labour market (re)-entry, including among lone parents. ${ }^{29}$ Housing tenure is known to be strongly associated with employment status, ${ }^{30}$ as well as a range of other unfavourable outcomes. While the causal relationship and direction between housing tenure and other outcomes is hard to determine precisely, it does appear that living in social housing is not solely a consequence of disadvantage in other domains, but may also shape outcomes. ${ }^{23}$ The analysis also included a measure of whether the family had experienced a geographical move between the two time points, and the distance moved. The economic variables are likely to be protective against joblessness, and geographical relocation may also imply a change in socioeconomic circumstances (including being associated with a move into work). The child's own age and sex were also included.

The variables included focused on the family (or parental) circumstances of the child and the more general household context. However, they were not exhaustive. This was partly for reasons of parsimony and the risks of overparameterising the model, given the small sample sizes of some ethnic groups, and partly to aid more direct interpretation. Other analysis of workless households (not focusing on ethnicity, and with a richer set of variables to choose from) has included a more complex range of variables, ${ }^{31}$ but that can come at the risk of rendering individual variables hard to interpret. Key variables that may be relevant to consider in future analysis are regional effects and household size/number of adults.

\section{Analytical approach}

Following inspection of the simple distributions of worklessness by ethnic group across the two time points and transitions between workless and non-workless states, binary logistic regression models were estimated for the probability of being in a workless household in 2001 conditioning on workless household status in 1991, and both with and without controlling for the household and family characteristics. This enabled entry, exit and persistence effectively to be summarised in a single model. By constructing a set of dummies that combined ethnic group and workless household status in 1991, the estimation allowed the association between workless household status in 1991 and 2002, that is, patterns of entry, exit and persistence, to vary by ethnic group, while still using the full estimation sample. Creating individual dummies for the combinations of ethnic group and household workless status avoids the problems of interpreting interaction effects in a logit model, ${ }^{32}$ while not forcing the impact of prior worklessness to be constant across groups. Not allowing for interactions would mean, given the numerical dominance of the White majority group, that the effect of worklessness in 1991 on workless household status in 2001, would be 
driven by the association for the white majority. In the results section, odds ratios are provided for combined ethnic group and 1991 workless households status effects. These capture entry rates relative to the reference category of White British children not living in a workless household in 1991, and persistence rates relative to the same reference group.

Given that persistence rates for those workless in 1991 are likely to be higher for all ethnic groups, including the White majority, compared to White majority children not workless in 1991, evaluation of whether there are differences in persistence between minorities and the majority was attempted, by testing the equality of the coefficients for each minority dummy for those in workless households in 1991 with the coefficient for White majority children workless in 1991.

\section{Results}

\section{Patterns of children's experience of workless households by ethnic group}

Figure 1 shows the simple proportions of the sample of children who experience worklessness at either time point. Overall, a substantial 21 per cent were living in a workless household in 1991 and this declined to 17 per cent by 2001 , a statistically significant change. ${ }^{33}$ Given that these are the same children who aged over the decade, this could be partly an age effect (that as the children become older, other members of their household become workers). For example, lone parents become freed for work $^{34}$ or older siblings still living in the household begin work. It could also be a structural effect related to the improvement in the economy and reduction of unemployment over time. The role of family and household characteristics in contributing to household worklessness and workless transitions is explored below. It is worth noting the very different rates of worklessness experienced across the groups. For most groups, except White Other and Pakistani children, there is a decline in household worklessness risks over time, though it is not statistically significant in all cases.

\section{Figure 1 Proportions of children in workless households at 1991 (aged 0-5 years) and 2001 (aged 10-15 years) by ethnic group, England and Wales}

Percentages

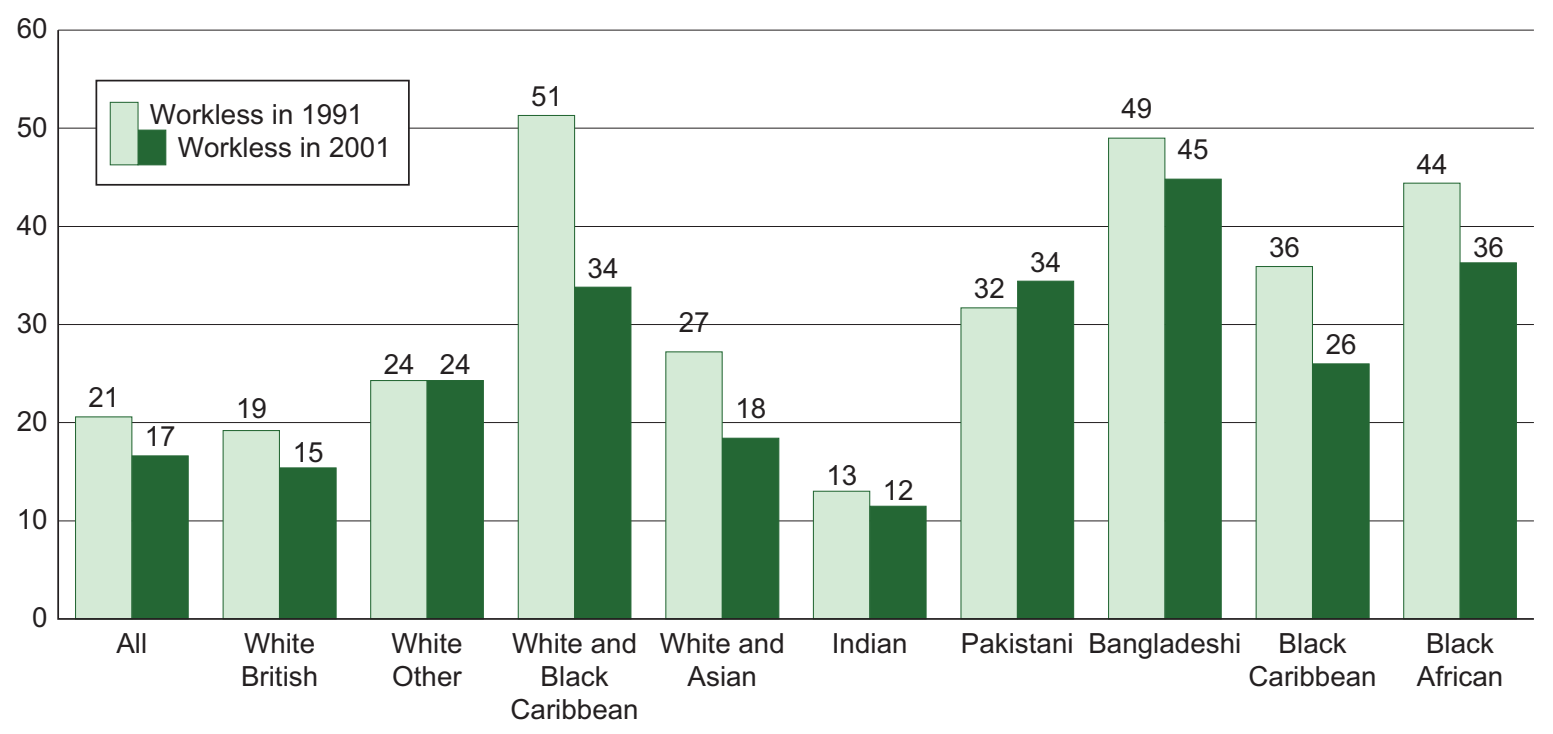

Source: ONS Longitudinal Study, author's analysis 


\section{Figure 2 Movers and stayers, children in workless households 1991-2001, by ethnic group}

Percentages

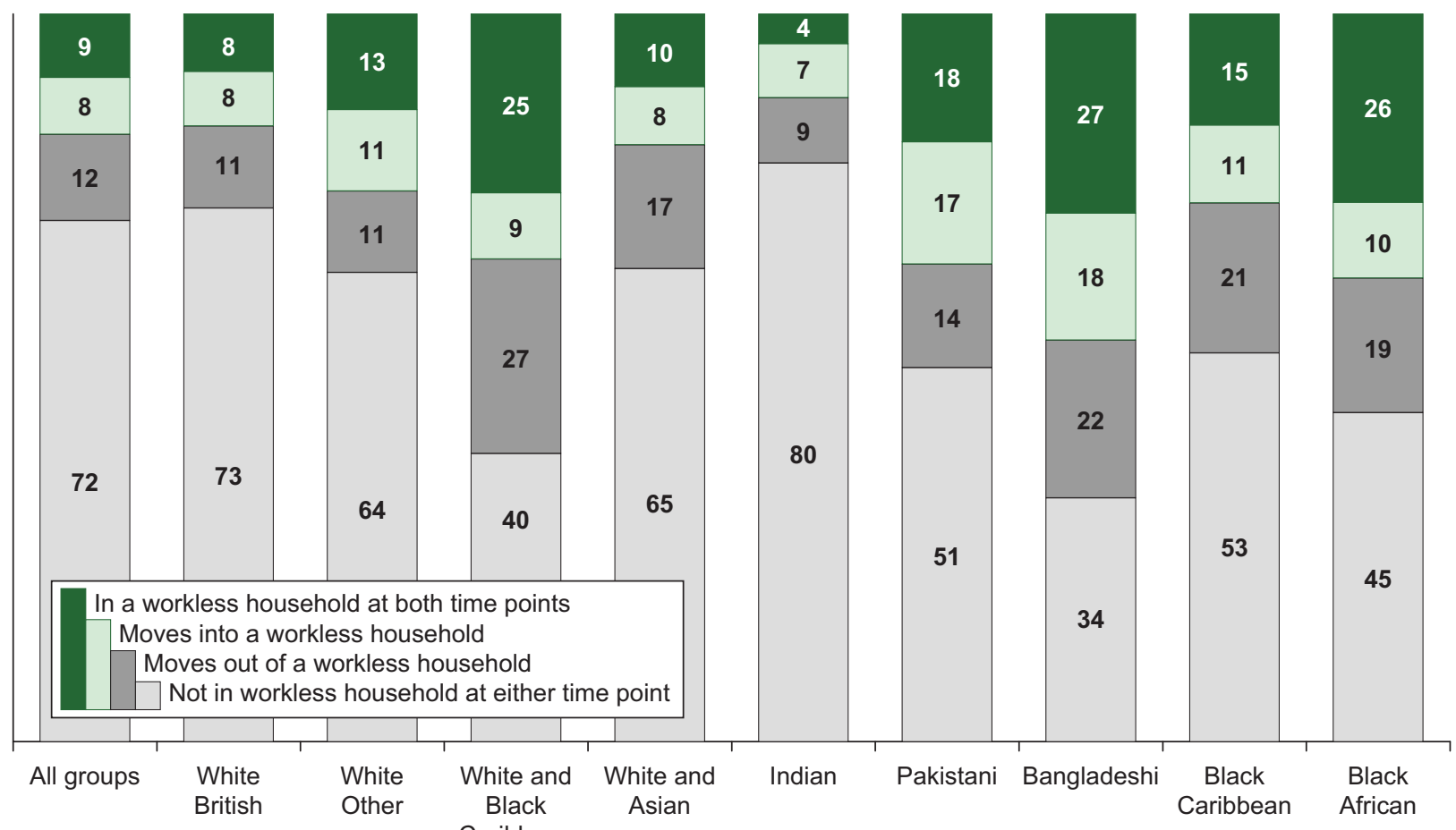

Source: ONS Longitudinal Study, author's analysis

Figure 2 divides these overall risks of living in a workless household at the two time points by looking at the actual patterns of movement in and out of a workless household for the children at either end of the decade. It shows those who were in a workless household at neither time point, those who moved out of one over the decade (exits), those who moved into one over the decade (entries) and those who were living in a workless household at both time points (persistence). Is it that the majority of those who are living in workless households in 1991 were also living in workless households in 2001, or is there a significant movement between one time point and the next?

It is clear from Figure 2 that experience of living in a workless household across the decade is a minority experience since 72 per cent of children lived in a working household at younger and older ages. Only nine per cent were living in a workless household at both ends of the decade. Of course, for the former group it cannot be assumed that they never experienced worklessness, nor that the latter group was continuously living in a workless household. For example, the extensive dynamics in poverty was documented by Jenkins and others.

However, those with continuous experience will be over represented in either group. ${ }^{38}$ Aside from these two groups of 'stayers', however, a fifth of young children (20 per cent) have either moved out of or into a workless household by the time they are aged 10-15.

There is additionally, substantial ethnic group variation in these patterns. With the exception of children in Indian families who are less likely to have experienced worklessness at either time point, the minority groups are all more likely than the white majority to have been in a workless household at one or other time, as well as to have experienced persistence, that is being in a 
workless household at both time points. The small sample sizes mean that not all the differences in persistence are statistically significant, but they differ significantly for Pakistani, Bangladeshi and Black African children compared to White British children. The proportions of all children who are persistently in workless households are particular high for White and Black Caribbean, Bangladeshi and Black African children: a quarter or more were living in a workless household at both time points. However, if we take the proportion in workless households as a proportion of all those workless at the first time point (that is the top green section over the top grey plus the first green sections combined) to be the persistence rate, that is the proportion of those children in workless households who are also in workless households at the second time point, we find a slightly different pattern. Indian children have the lowest persistence rates at 31 per cent, followed by 37 per cent for White and Asian children, 42 per cent for White British and Black Caribbean children, 48 per cent for White and Black Caribbean children, around 55 per cent for White Other, Pakistani and Bangladeshi children and to 58 per cent for Black African children.

The patterns of transitions are also varied. Pakistani and Bangladeshi children have high rates of entry into worklessness: 17 and 18 per cent respectively of children from these groups moved into a workless household. As a proportion of those not workless at the first time point, this amounts to entry rates of 25 per cent and 35 per cent respectively, compared to only ten per cent for White British children.

While in general there is a slight tendency of workless household rates to reduce with time (and age) - and this is particularly true for White and Black Caribbean children - Pakistani children (where moves into worklessness outweigh moves out of it) have in fact higher risks of living in a workless household at the later time point.

\section{Estimating 'ethnic penalties' in children's workless household persistence}

Table 4 shows the results from models estimating the impact of ethnic group and workless household status on chances of being in a workless household in 2001. In model 1 only the dummies created by interacting all 'ethnic group' categories with '1991 workless household status' (in working household 1991 / in workless household 1991) were included, whereas model 2 also included the full set of household and family characteristics.

Variables which were particularly strongly associated with persistence in or entry to workless households status in 2001 included family structure. 'Presence of a father in 2001', was found to be negatively and significantly associated with workless household status (odds ratio $=0.34$ ). The variable 'number and increase in siblings' was also positively associated with living in a workless household in 2001. Parental qualifications at every level decreased chances of living in a workless household in 2001 relative to having no qualifications. Housing tenure was strongly associated with worklessness. Both private tenancy and social housing had odds ratios of over 5 relative to living in owner occupation. Change in housing tenure (that is into owner occupation) moderated this effect slightly as it was negatively associated with remaining or becoming workless by 2001 (odds ratio $=0.81$ ). Car ownership in 1991 was also negatively associated with workless household status ten years later, consistent with expectations. While it is not possible to disentangle the causal relationships in every case, the indication is that prior household resources as well as parental qualifications and family structure are all implicated in children's vulnerability to worklessness over time. These are areas that are already recognised as affecting children's opportunities. 


\section{Table $4 \quad$ Relative chances of being in a workless households in 2001 conditional on 1991 workless household status, by ethnic group}

\begin{tabular}{|c|c|c|}
\hline Ethnic group & Household work status in 1991 & $\begin{array}{r}\text { Model } 1 \\
\text { Simple model }\end{array}$ \\
\hline
\end{tabular}

Reference: white not workless

White British

White other

White and Black Caribbean

Indian

Pakistani

Bangladeshi

Black Caribbean

Black African

Number in analysis

33,051

P values: $+<0.1 ;{ }^{*}<=0.05 ;{ }^{* *}<=0.01 ;{ }^{* * *}<=0.001$.

Values that are not statistically significant are indicated in italics.

Note: Model 1 includes ethnicity and workless household status in 1991.

Model 2 adds the household and parental characteristics outlined in Section 2.

Source: ONS Longitudinal Study, author's analysis

\begin{tabular}{|c|c|}
\hline $7.9^{\star \star \star *}$ & $2.14^{* * *}$ \\
\hline 1.4 & $1.70^{*}$ \\
\hline $15.3^{\star * *}$ & $4.43^{\star * *}$ \\
\hline $6.27(1)^{*}$ & $5.47(1)^{*}$ \\
\hline $2.56^{* * *}$ & 1.42 \\
\hline $10.07^{\star * *}$ & $1.89^{\star * *}$ \\
\hline $2.38(1)$ & $0.53(1)$ \\
\hline 1.26 & 1.08 \\
\hline $5.98^{* * *}$ & $2.25^{*}$ \\
\hline $0.99(1)$ & $0.02(1)$ \\
\hline 0.79 & 0.99 \\
\hline $4.95^{\star * *}$ & $3.01^{* * *}$ \\
\hline $3.69+$ & $1.32(1)$ \\
\hline $3.25^{\star * *}$ & $2.56^{\star * *}$ \\
\hline $14.15^{\star \star *}$ & $8.92^{* * *}$ \\
\hline $0.98(1)^{\star * *}$ & $38.96(1)^{* \star *}$ \\
\hline $5.05^{\star * *}$ & $2.11^{* *}$ \\
\hline $12.43^{\star \star *}$ & $2.41^{*}$ \\
\hline $4.32(1)^{*}$ & $0.18(1)$ \\
\hline $1.95^{\star * *}$ & 0.9 \\
\hline $7.92^{* * *}$ & $1.83^{*}$ \\
\hline $0.00(1)$ & $0.38(1)$ \\
\hline $2.83^{* * *}$ & 1.43 \\
\hline $9.30^{* * *}$ & $2.72^{*}$ \\
\hline $0.24(1)$ & $0.36(1)$ \\
\hline
\end{tabular}

In workless household 1991 (odds ratio)

in working hh 1991 [relative entry compared to

In workless hh 1991 [compared to White British not workless]

workless [relative persistence compared to

hite British] (Chi ${ }^{2}$ (df))

In workless hh 1991 (odds ratio)

Difference from White British workless

[relative persistence] $\mathrm{Chi}^{2}$ (df)

in working hh 1991 [relative entry] (odds ratio)

In workless hh 1991 (odds ratio)

$2.25^{*}$

(O)

Workless (odds ratio)

Difference from White British workless

[relative persistence] $\mathrm{Chi}^{2}$ (df)

in working hh 1991 [relative entry] (odds ratio)

$92^{* * *}$

Difference from White British workless

[relative persistence] $\mathrm{Chi}^{2}$ (df)

in working hh 1991 [relative entry] (odds ratio)

$11^{* *}$

$2.41^{*}$

Difference from White British workless

[relative persistence] $\mathrm{Chi}^{2}$ (df)

In workless hh 1991 (odds ratio)

0.9

$1.83^{*}$

Difference from White British workless

[relative persistence] $\mathrm{Chi}^{2}$ (df)

1.43

In workless hh 1991 (odds ratio)

$0.36(1)$

Difference from White British workless

[relative persistence] $\mathrm{Chi}^{2}$ (df)

$0.24(1)$ 
For estimating the relative impact of combined ethnic group and 1991 household work status, the reference category is White British children living in a working household in 1991. We would expect that for all children the chance of living in a workless household in 2001 is higher if they were already living in a workless household at the earlier point, both in absolute terms and when holding family characteristics constant. The 'workless' rows in the table show that this is true for White British children who are workless in 1991, and for other groups who are living in workless households in 1991, relative to White British children not living in a workless household in 1991. This then simply tells us about the tendency of workless household status to persist over time.

The 'in work' row in Table 4 for each minority group illustrates the relative chance of being in a workless household in 2001, given that the child was living in a working household in 1991, compared to the White British children in working households in 1991. It shows whether minority groups face a greater risk of entry into worklessness compared to the White British majority. In a situation of ethnic equality we would expect all these coefficients to be statistically no different from the reference category of White British children living in a working household at a young age. Instead, it was found that Pakistani, Bangladeshi, Black Caribbean and Black African children faced greater risks of entry into a workless household in absolute terms (Model 1), consistent with what we saw in Figure 2. However, on controlling for household and family characteristics, the Black Caribbean and Black African children no longer face relatively higher risk of entry; that is, their greater risk can be explained in terms of living in family types or experiencing changes in household or family characteristics placing them at greater risk of entry, but they appear to face no additional vulnerability to becoming workless. By contrast children in the White Other group appear to live in family types that tend to be less vulnerable to becoming workless since, when family and household characteristics are controlled for, they experience greater risk of workless household entry compared to their White British counterparts. Pakistani and Bangladeshi children also had significantly higher rates of entry into worklessness in model 2 than their White British comparators, but for these children the effects were reduced when family and contextual characteristics were held constant.

The third row for each minority group in Table 4 indicates the differences in the risk for children of remaining in a workless household over time, by ethnic group. Any statistically significant difference between the coefficients implies that the chance of remaining in a workless household (persistence) is greater for the minority group. This statistically significant result suggests that exit from workless household status over the ten-year period is harder to achieve for that group compared to the majority of children.

For White Other, Pakistani and Bangladeshi children, there was a significantly greater absolute risk of persistence. In Model 2 the increased risk remains for White Other and Pakistani children, but was not observed for Bangladeshi children once controlled for household and family characteristics. This suggests that White Other and Pakistani children face an 'ethnic penalty' in their chance of remaining in (or returning to) a workless household over a ten-year period. Their increased persistence in a workless household cannot be fully accounted for by family or household characteristics placing them at greater risk of worklessness. By contrast, the greater persistence experienced by Bangladeshi children would appear to be more readily accounted for by family and household characteristics that make them more vulnerable to worklessness.

To illustrate the magnitude of these effects, while a White British child with average characteristics from this cohort has a six per cent chance of entering worklessness by 2001 , a Pakistani child with 
the same family and household characteristics has a 15 per cent chance. A White British child with average characteristics but living in a workless household in 1991 has a 13 per cent chance of still being there in 2001 , but for a Pakistani child living in comparable family circumstances, the chance is 27 per cent. $^{39}$

\section{Discussion}

This article has exploited the unique features of the ONS Longitudinal Study to examine the risk of living and remaining in a workless household for a single cohort of children over a common period and at a ten year interval. It set out to examine the chances of worklessness over time and for a group of children subject to comparable economic circumstances when growing up, and to investigate the extent to which there appeared to be differential risk of remaining in a workless household over time by ethnic group.

Understanding of ethnic group differences in child welfare, particularly in duration and persistence of deprivation, remains limited, despite some recognition of the labour market penalties experienced by minority groups. ${ }^{40}$ This article set out to understand the extent to which differences were mediated by family characteristics and household circumstances, which are subject to direct policy interest, ${ }^{4,5,18}$ and the existence of ethnic penalties.

Analyses have shown that there are dramatic differences in the chance of remaining in or entering a workless household for this cohort of children by ethnic group. Indian children had the lowest chance of having lived in a workless household at either time point, while mixed White and Black Caribbean children had the highest. For those children who ever lived in a workless household, there were differences in their vulnerability to remaining in a workless household and to entering a workless household from a working household.

Estimating the chance of being in a workless household in 2001, when controlling for a range of family and household characteristics and conditioning on household work status at 1991, showed that for children from other groups, the absolute difference in chances of living in a workless household were mediated by family structure and household circumstances. Nevertheless, Pakistani and White Other children faced statistically significantly greater chances of both remaining in a workless household and of entering a workless household when such family and household characteristics were held constant. Bangladeshi children also experienced higher rates of entry into worklessness than otherwise similarly situated White majority children. The findings for White Other children were not apparent in other labour market studies. For Pakistani children the increased risk is consistent with findings elsewhere ${ }^{21,41}$ despite increases in educational level and other apparently protective factors.

Of course, estimating 'ethnic penalties' across 'otherwise similar' children does not take account of family characteristics that may operate in different ways for different groups. In particular, housing tenure has been shown to have different meanings for some groups, with owner occupation operating as a potential constraint as much as an economic resource. ${ }^{42}$ Moreover, ethnic groups' geographical distribution leads to greater concentration of some groups in higher unemployment areas. Part of the 'ethnic penalty' can stem from living in a location where there are fewer - or declining - opportunities more generally. Future analysis could explore the role of regional effects. However, consistent with analysis by Simpson et al., ${ }^{43}$ preliminary area-based investigation did not indicate that this was the only factor accounting for the additional risk of living in a workless household faced by children from ethnic minority groups. 
This article studies just one cohort of children, avoiding problems of changing labour market conditions which could influence outcomes. But in doing that it can only really speak to this cohort. The ONS Longitudinal Study enables persistence in worklessness to be examined over a relatively long period, allowing early and middle/late child experience to be compared. This comes at the cost of being able to study only two time points, with intervening experiences remaining unknown. The discussion of 'persistence' is therefore subject to some caveats. The advantage of the ONS Longitudinal study is that its sample size allows direct analysis of ethnic difference; however, when exploring specific cohorts, some sample size issues still arise.

Despite limitations, these findings shed new light on children's experience of living in a workless household over time by ethnic group. If the experience of worklessness in childhood has longterm effects, there should be concern for the future of these groups, particularly those at risk of persistent (or repeated) worklessness. The evidence for some groups suffering 'ethnic penalties' in worklessness should lead to questioning the extent to which these penalties will be addressed by current policies to increase workforce participation in families with children.

\section{Acknowledgments}

The permission of the Office for National Statistics to use the Longitudinal Study is gratefully acknowledged, as is the help provided by staff of the Centre for Longitudinal Study Information and User Support (CeLSIUS). CeLSIUS is supported by the ESRC Census of Population Programme (Award Ref: RES-348-25-0004).

This work contains statistical data from ONS which is Crown copyright and reproduced with the permission of the controller of HMSO and Queen's Printer for Scotland. The use of the ONS statistical data in this work does not imply the endorsement of the ONS in relation to the interpretation or analysis of the statistical data. This work uses research datasets which may not exactly reproduce National Statistics aggregates. The author alone is responsible for the interpretation of the data. 


\section{Appendix}

\section{Figure A1 Employment status by gender and ethnicity (percentages)}

Percentages

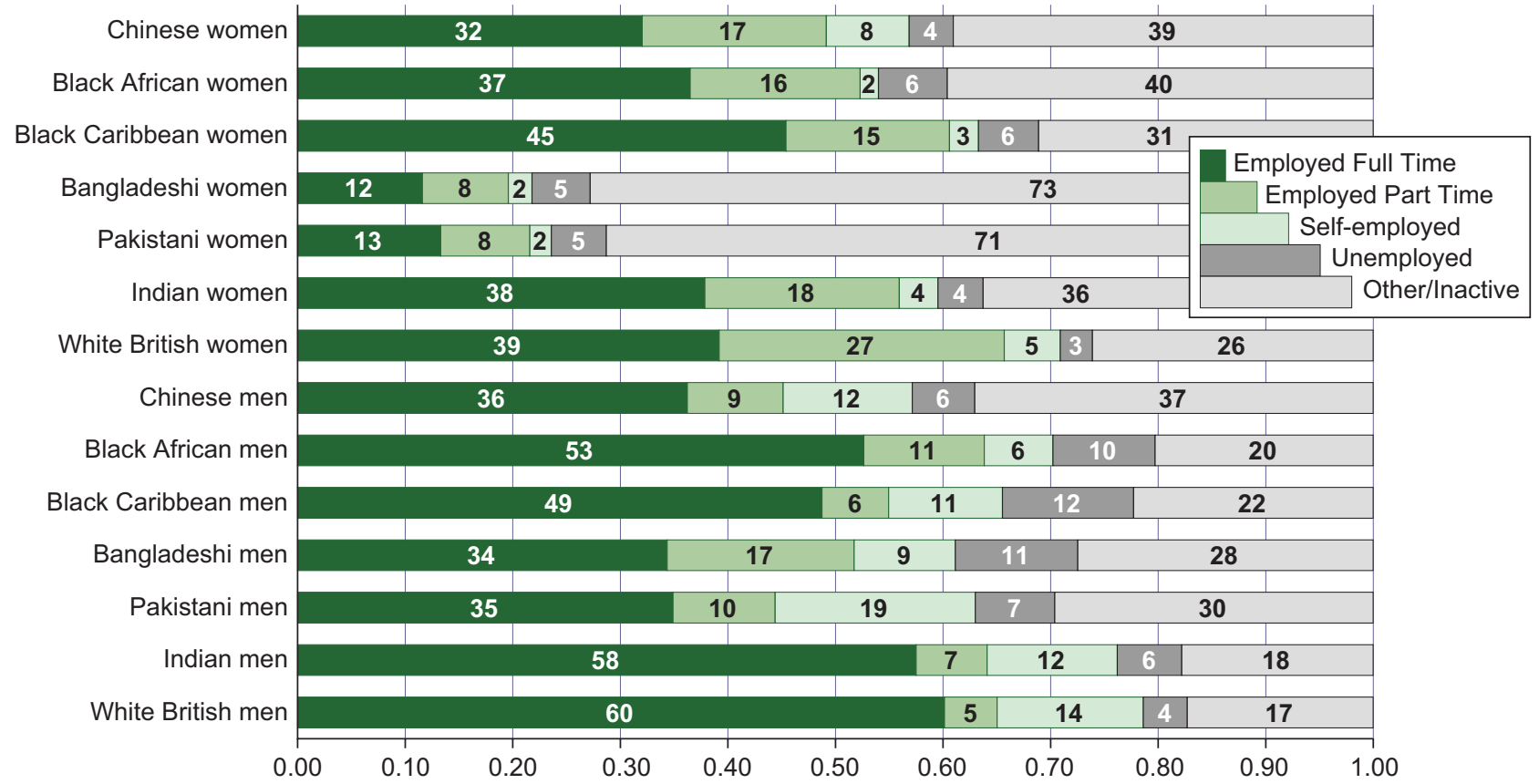

Source: Longhi and Platt (2008) 'Pay Gaps Across Equalities Areas', Figure 2.1

\section{References}

1 Department for Work and Pensions (2005) Department for Work and Pensions five year strategy: opportunity and security throughout life, London: Stationery Office.

2 Gregg, P and Wadsworth, J (1996) 'More work in fewer households?' in J. Hills (ed) New inequalities: the changing distribution of income and wealth in the United Kingdom, Cambridge: Cambridge University Press.

3 Gregg, P and Wadsworth, J (2001) 'Everything you ever wanted to know about measuring worklessness and polarization at the household level, but were afraid to ask', Oxford Bulletin of Economics and Statistics 63: 777-806.

4 Child Poverty Unit (2009) Ending Child Poverty: Making it happen, London: Child Poverty Unit.

5 HM Treasury, Department for Work and Pensions and Department for Children, Schools and Families (2008) Ending Child Poverty: Everybody's business, Budget 2008 Report. London: HM Treasury.

6 Nickell, S (2004) 'Poverty and worklessness in Britain', The Economic Journal 114, C1-C25.

7 Platt, L (2009) Ethnicity and child poverty, Department for Work and Pensions Research Report No 576. Leeds: Corporate Document Services.

8 In the vast majority of households children are living with at least one parent, and for children of the age range covered in this analysis (0-15), most will be living with a parent of working age. A small number of children will be living with adults other than parents, and a small 
number will be living only with adults over pension age, whether parents or not. But from the perspective of this analysis, which is the impact that worklessness has on children, these situations are not excluded. It is a moot question whether it is more appropriate to investigate workless households or workless families (HM Treasury, 2008). It is conventional to look at the household as a whole and accords more with the aim of the article, where any household employment, even if not within the nuclear family, is likely to have an impact on children's poverty risks and will provide them with some role model or familiarity with a employment. Separate analyses were conducted using a family definition, and in order to answer somewhat different questions, but it is beyond the scope of this article to cite them here.

9 Such, E and Walker, R (2002) 'Falling behind? Research on transmitted deprivation', Benefits 10(3): 185-192.

10 Duncan, G G, Brooks-Gunn, J, Yeung, W J and Smith, J R (1998) 'How much does childhood poverty affect the life chances of children?' American Sociological Review 63(3): 406-423.

11 Ermisch, J, Francesconi, M and Pevalin, D J (2004) 'Parental partnership and joblessness in childhood and their influence on young people's outcomes', Journal of the Royal Statistical Society A 167(1): 69-101.

12 Vleminckx, K and Smeeding, T M (eds) 2001 Child Well-Being, Child Poverty and Child Policy in Modern Nations: What do we know? Bristol: The Policy Press.

13 Schoon, I, Sacker, A and Bartley, M (2003) 'Socio-economic adversity and psychosocial adjustment: a developmental contextual perspective', Social Science and Medicine 57: 10011015.

14 Bradbury, B, Jenkins, S P and Micklewright, J (eds) (2001) The Dynamics of Child Poverty in Industrialised Countries, Cambridge: Cambridge University Press.

15 Hills, J, McKnight, A, Smithies, R (2006) Tracking Income: How working families' incomes vary through the year. CASEreport 32. London: Centre for Analysis of Social Exclusion.

16 Smith, N and Middleton, S (2007) A Review of Poverty Dynamics Research in the UK. York: Joseph Rowntree Foundation.

17 Jarvis, S and Jenkins, S P (1997) 'Low income dynamics in 1990s Britain.' Fiscal Studies 18(2): 123-142.

18 Platt, L (2006) 'Social insecurity: children and benefit dynamics', Journal of Social Policy, 35(3): $391-410$.

19 Department for Work and Pensions (2009) Households Below Average Income, 1994/952007/08. London: DWP.

21 Gottschalk, P (1992) 'The intergenerational transmission of welfare participation: facts and possible causes', Journal of Policy Analysis and Management 11(2): 254-272.

22 Platt, L (2006) 'Social insecurity: children and benefit dynamics', Journal of Social Policy 35(3).

23 Platt, L (1997) Poverty and Ethnicity in the UK. Bristol: The Policy Press.

24 See, for example, the discussion of the literature on employment and ethnicity in Platt, L (2005) Migration and social mobility: The life chances of Britain's minority ethnic communities, Bristol: The Policy Press. 
25 Department for Work and Pensions (2007) Ready for Work: Full employment in our generation, Cm 7290. London: The Stationery Office.

26 Even though worklessness is defined at the household level, I have explored the association of 'family' characteristics with that outcome (i.e. parental characteristics and family structure). When it is the child (rather than the household or the family) which is the unit of analysis, this is unproblematic (compare poverty analysis where poverty is defined at the household level but family as well as household characteristics are invoked to 'explain' it). Throughout the article, I have therefore used family to refer to family type (e.g. lone parenthood) or parental attributes, even in the context of measuring outcomes at the household level.

27 Heath, A and McMahon, D (1997) 'Education and occupational attainments: the impact of ethnic origins', in V. Karn (ed) Ethnicity in the 1991 Census: Volume Four: Employment, education and housing among the ethnic minority populations of Britain, London: HMSO.

28 Platt, L, Simpson, L and Akinwale, B (2005) 'Stability and change in ethnic group in England and Wales', Population Trends 121: 35-46.

29 Shaw, A, Walker, R, Ashworth, K, Jenkins, S and Middleton, S (1996) Moving off Income Support: Barriers and bridges, Department of Social Security Research Report No. 53. London: HMSO.

30 Hills, J, Brewer, M, Jenkins, S, Lister, R, Lupton, R, Machin, S, Mills, C, Modood, T, Rees, T and Riddell, S (2010) An Anatomy of Economic Inequality in the UK: Report of the National Equality Panel, London: Government Equalities Office / Centre for Analysis of Social Exclusion.

31 Hérault, N, Kalb, G, Mavromaras, K, Platt, L and Zakirova, R (2009) Dynamics of Household Joblessness in Australia, Report of Melbourne Institute of Applied Economic and Social Research for Australian Government Department of Education, Employment and Workplace Relations. Melbourne: University of Melbourne.

$32 \mathrm{Ai}, \mathrm{C}$ R and Norton, E C (2003) 'Interaction terms in logit and probit models', Economics Letters 80(1): 123-129.

33 The figure of 17 per cent for 2001 is slightly higher than the 16 per cent for the White majority children shown in Table 1. But, while the rates are similar, the ONS LS sample is a specific cohort and we would not necessarily expect its experience to parallel that of all children.

34 We already know that there is an age of child effect for lone parents' labour market (re)-entry; and this is evidence that the new Lone Parent Obligations (DWP, 2007) are building upon.

35 Jarvis, S and Jenkins, S (1997) 'Low income dynamics in 1990s Britain', Fiscal Studies 8: 123142.

36 Hill, M and Jenkins, S P (2001) 'Poverty amongst British children: chronic or transitory?' in B. Bradbury, S. P. Jenkins and J. Micklewright (eds) The Dynamics of Child Poverty in Industrialised Countries, Cambridge: Cambridge University Press.

37 Jenkins, S P and Rigg, J A (2001) The Dynamics of Poverty in Britain, Department for Work and Pensions Research Report 157, London: DWP.

38 Bane, M J and Ellwood, D T (1994) 'Understanding welfare dynamics', in M. J. Bane and D. T. Ellwood (eds) Welfare realities: from rhetoric to reform, Cambridge, Massachusetts: Harvard University Press. 
39 These predicted persistence rates are much lower than the ones we see in the raw data (Figure 2) of around 42 per cent and 56 per cent, because the children more likely to be workless in 1991 are not living in 'average' family circumstances.

40 Heath, A and Cheung, S Y (2006) Ethnic Penalties in the Labour Market: Employers and discrimination, Department for Work and Pensions Research Report 341. Leeds: Corporate Document Services.

41 Longhi, S and Platt, L (2008) Pay Gaps Across Equalities Areas, EHRC Research Report nr 9. Manchester: Equalities and Human Rights Commission.

42 Phillips, D (1997) 'The housing position of ethnic minority group home owners', in V. Karn (ed) Ethnicity in the 1991 Census: Volume Four: Employment, education and housing among the ethnic minority populations of Britain, London: The Stationery Office.

43 Simpson, L, Purdam, K, Tajar, A, Pritchard, J A D and Dorling, D (2009) 'Jobs deficits, neighbourhood effects, and ethnic penalties: the geography of ethnic-labour-market inequality', Environment and Planning A 41(4): 946-63. 